\title{
Waarheidsplicht en bewijslastverdeling
}

\author{
Redouan El Gamali en Eric Tjong Tjin Tai*
}

\section{Inleiding}

Sinds januari 2002 is in art. $21 \mathrm{Rv}$ de zogenaamde waarheidsplicht neergelegd. ${ }^{1}$ Deze plicht omvat niet alleen een verplichting tot het aanvoeren van alle relevante feiten (stellingen), maar ook een verplichting tot het aanvoeren van bewijsmateriaal. ${ }^{3}$ De waarheidsplicht wordt door veel auteurs inmiddels beschouwd als een uitgangspunt van het procesrecht. ${ }^{4}$ Kritiek is er ook, met name omdat hiermee afstand werd genomen van de traditionele lijdelijkheid van de rechter. ${ }^{5}$ Het wetsvoorstel vereenvoudiging en modernisering bewijsrecht, waar in 2018 een consultatieronde over is gehouden, ${ }^{6}$ gaat niettemin op de ingeslagen weg voort en stelt de waarheidsplicht voorop door in principe te verlangen dat partijen aan het begin reeds alle relevante materialen overleggen, ${ }^{7}$ liefst inclusief schriftelijke

\footnotetext{
Mr. R. El Gamali is advocaat bij Pels Rijcken te Den Haag en afgestudeerd aan Tilburg Law School. Prof. mr. ir. T.F.E. Tjong Tjin Tai is hoogleraar privaatrecht aan Tilburg University en onderzoeker bij het Tilburg Instituut voor Privaatrecht (TIP).

Dit artikel is mede gebaseerd op de afstudeerscriptie van eerstgenoemde auteur.

1. Deze verplichting geldt zowel voor de verzoekprocedures, alsook voor de vorderingsprocedures; zie HR 25 maart 2011, ECLI:NL:HR: 2011:BO9675.

2. In dit artikel zal niet worden ingegaan op de verplichting om feitelijke stellingen naar waarheid aan te voeren. In deze bijdrage zal enkel worden ingegaan op de plicht om bewijsmateriaal over te leggen dat van belang is voor de rechter teneinde een beslissing te kunnen nemen op basis van de werkelijke gang van zaken. De keuze voor dit onderdeel van de waarheidsplicht is gelegen in de confrontatie en interactie met de bewijslastverdeling ex art. $150 \mathrm{Rv}$.

3. Parl. Gesch. Herziening burgerlijk procesrecht, 2002, p. 147 en 152-153; R.H. de Bock, Tussen waarheid en onzekerheid: over het vaststellen van feiten in de civiele procedure (diss. Tilburg), Deventer: Kluwer 2011, p. 54.

4. Zie A. Hammerstein, R.H. de Bock \& W.D.H. Asser, Modernisering burgerlijk bewijsrecht, Den Haag: Boom juridisch 2017, p. 11; Asser Procesrecht/Asser 32017/75; De Bock 2011, p. 72.

5. Zie bijv. A.C. van Schaick, Het burgerlijk recht de baas? Over de verwevenheid van burgerlijk recht en burgerlijk procesrecht (oratie Tilburg), Deventer: Kluwer 2009, p. 53 en 55; G.C.C. Lewin, Het burgerlijk procesrecht is de pathologie van het recht (oratie Amsterdam (UvA)), Amsterdam: Vossiuspers 2013, p. 7-8; W. Heemskerk, Hoofdlijnen van Nederlands burgerlijk procesrecht, Dordrecht: Convoy Uitgevers 2015, p. 12; Asser Procesrecht/Van Schaick 2 2016/92 e.v.; zie anders De Bock 2011, p. 85; Asser Procesrecht/Giesen 1 2015/496; H.J. Snijders, C.J.M. Klaassen \& G.J. Meijer, Nederlands burgerlijk procesrecht, Deventer: Kluwer 2011, p. 61.

6. Zie www.internetconsultatie.nl/bewijsrecht.

7. Zie art. 149 a van het voorstel.

8. Zie art. 30a lid 3 sub g en 30 i lid 6 van het voorstel.
}

getuigenverklaringen. ${ }^{8}$ Ook dit voorstel ontmoet weerstand, om diverse praktische en principiële redenen. ${ }^{9}$

In de discussie over de waarheidsplicht is echter weinig aandacht besteed aan het gegeven dat het Nederlands burgerlijk procesrecht al van oudsher een rechtsfiguur kent om partijen te prikkelen bewijsmateriaal aan te dragen, te weten het leerstuk van de bewijslastverdeling (art. $150 \mathrm{Rv}$ ). Beide leerstukken overlappen, wat in de praktijk problematisch kan zijn. Een voorbeeld is dat eiser de bewijslast draagt van een cruciaal feit, maar verweerder ${ }^{10}$ over het relevante bewijsmateriaal beschikt en dat niet in het geding brengt. ${ }^{11}$ In zo'n geval zou de rechter volgens de regels van bewijslastverdeling de vordering moeten afwijzen, terwijl de schending van art. $21 \mathrm{Rv}$ juist zou nopen tot een sanctie als verwerping van het standpunt van verweerder en toewijzing van de vordering. ${ }^{12} \mathrm{De}$ leerstukken wijzen in dat geval in tegengestelde richtingen.

In deze bijdrage zal de verhouding tussen de waarheidsplicht en de bewijslastverdeling aan een nader onderzoek worden onderworpen. Dit heeft een theoretische component, alsook een praktische: welke sancties moet de rechter toepassen? Allereerst zal beknopt de historie van de bewijslastverdeling worden behandeld, aangezien daaruit blijkt dat er opvallende voorlopers zijn van de hedendaagse discussie over de waarheidsplicht (par. 2). Daarnaast laat de discussie over bewijslastverdeling en de nuances die daarop zijn aangebracht enige complicaties zien die bij een ruime toepassing van de waarheidsplicht kunnen optreden. Vervolgens zal worden ingegaan op achtergrond en inhoud van de waarheidsplicht, en wordt de bewijslastverdeling theoretisch geplaatst ten opzichte van de waarheidsplicht (par. 3). Daarna wordt de praktische uitwerking van de interactie tussen de bewijslastverdeling en de waarheidsplicht behandeld, waarbij de nadruk ligt op de toepassing van sancties (par. 4). Hierbij zullen enkele tekort-

9. Zie bijv. NVvP, Vernieuwingen in het civiele bewijsrecht, Den Haag 2018; J.W. Alt, 'Na een reset van KEI ook een reset voor het burgerlijk procesrecht in vorderingszaken?', NJB 2018/1759; M. de Boer \& M. de Monchy, 'Kroniek van het burgerlijk procesrecht', NJB 2018/1869; F.J.P. Lock, 'Nieuw bewijsrecht, maar geen recht op bewijs?', TCR 2018, afl. 4, p. 91-92; R.R. Verkerk, 'De modernisering van het getuigenverhoor', TCR 2018, afl. 3, p. 71-78.

10. Wij spreken hier steeds van verweerder, conform de bij sommige gerechten geldende KEI-wetgeving.

11. Wij laten ten behoeve van het argument buiten beschouwing dat eiser, indien hij zeker weet dat verweerder over deze gegevens beschikt, ook art. 843a Rv kan inroepen.

12. Zie par. 3 over de toepasselijke sancties. 
komingen van de waarheidsplicht worden aangestipt. Vervolgens wordt beoordeeld of het voorstel tot herziening van het bewijsrecht verbetering brengt (par. 5). Tot slot volgt een conclusie (par. 6).

\section{De bewijslastverdeling ${ }^{13}$}

\subsection{Bewijslast als prikkel voor bewijs aandragen}

De rechter die een uitspraak moet doen, moet kennis hebben van de feitelijke gronden van het geschil. Voor zover partijen het daar niet over eens zijn, zal de rechter moeten beslissen welke feitelijke voorstelling van zaken juist is, 'waar' is. Van oudsher geldt hierbij het uitgangspunt van partijautonomie: ${ }^{14}$ partijen dragen het bewijsmateriaal aan binnen de daarvoor geldende regels. ${ }^{15}$ Men zou kunnen denken dat dit voldoende is: elke partij is immers gemotiveerd om zo veel mogelijk materiaal dat in haar eigen voordeel is aan te dragen, en doordat beide partijen hiertoe in de gelegenheid zijn, komt vanzelf al het benodigde materiaal in het geding. In de praktijk stuit dit op twee bezwaren: ten eerste is mogelijk dat bepaald (belastend) materiaal alleen ter beschikking staat van een partij waarvoor dit nadelig is, ten tweede is mogelijk dat een partij minder goed in staat is (wegens beperkte financiële middelen of anderszins) om materiaal te verzamelen. Toch is uitgangspunt van het bewijsrecht inderdaad dat partijen zelf materiaal aandragen. De bewijslast is vooral van belang omdat deze bepaalt bij wie het bewijsrisico ligt indien de rechter geen van beide standpunten overtuigend bewezen acht: in geval van zo'n non liquet wijst de rechter dan het standpunt af van degene op wie de bewijslast rust. ${ }^{16}$ Hierbij hoort overigens ook dat die partij, indien een toereikend bewijsaanbod is gedaan, dan wel de gelegenheid krijgt om aanvullend bewijs (met name getuigenbewijs) te leveren.

\subsection{De gematigd objectieve leer}

Voor de verdeling van de bewijslast zijn in het verleden verschillende theorieën verdedigd.

In Nederland ging de discussie vooral tussen de objectiefrechtelijke theorie en de billijkheidsleer. De wetgever heeft uiteindelijk gekozen voor de objectiefrechtelijke theorie. Asser verdedigde deze theorie door te wijzen op de praktische en theoretische toepassing daarvan. ${ }^{17}$ Kort gezegd houdt deze theorie in dat uit het objectieve, materiële recht, welk recht in concreto het geschil beheerst, gedestilleerd kan worden welke

13. Zie nader over de bewijslastverdeling Pitlo/G.R. Rutgers \& H.B. Krans, Bewijs, Deventer: Kluwer 2014, p. 39-41; H.J.W. Alt, Stelplicht en bewijslast in het nieuwe arbeidsrecht, Deventer: Wolters Kluwer 2017, p. 48 e.v.; H.J. Snijders, C.J.M. Klaassen \& G.J. Meijer, Nederlands burgerlijk procesrecht, Deventer: Wolters Kluwer 2017, p. 276 e.v.; Asser Procesrecht/Asser $32017 / 287$ e.v.; HR 9 september 2005, ECLI:NL:HR:2005:AT5156, NJ 2005/468 (Kroymans/Verploegen).

14. Zie bijv. Asser Procesrecht/Asser 3 2017/91, Pitlo/Rutgers \& Krans 2014, p. 29-30.

15. Deze zijn tegenwoordig ruimer dan vroeger; vroeger gold een gesloten stelsel van bewijsmiddelen.

16. Asser Procesrecht/Asser $32017 / 287$ e.v.

17. W.D.H. Asser, Bewijslastverdeling, Deventer: Kluwer 1992, p. 51-52; zie ook W.D.H. Asser, Bewijslastverdeling, Deventer: Kluwer 2004, p. 58. feiten gesteld en bewezen moeten worden teneinde een door een partij beoogd rechtsgevolg te doen intreden. ${ }^{18} \mathrm{Bij}$ de objectiefrechtelijke theorie wordt het materiële recht als uitgangspunt genomen. Als belangrijkste voordeel werd genoemd de grote voorspelbaarheid en controleerbaarheid van de uitkomsten. ${ }^{19}$ Een bijkomend voordeel is dat een partij van tevoren weet of zij relevant bewijsmateriaal moet bewaren. In veel gevallen leidt de objectieve leer er ook toe dat de bewijslast op de voor de hand liggende partij komt te rusten: het is immers meestal de afwijking van de gewone stand van zaken die moet worden bewezen, en daar draagt de eiser (die zich beroept op zo'n afwijking) meestal de bewijslast voor. Overigens is deze argumentatie minder overtuigend als de uitzondering gemakkelijker door de wederpartij is te ontkrachten en het ook logischer is dat die aantoont dat die uitzondering niet van toepassing is. ${ }^{20}$

Hiertegenover stond de billijkheidsleer. Deze leer hield in dat moest worden beoordeeld bij welke partij het in de gegeven omstandigheden het meest billijk zou zijn dat de bewijslast zou komen te liggen in de concrete processuele verhoudingen. ${ }^{21}$ Voor het bepalen van de bewijslast werden verschillende gezichtspunten voorgesteld, ${ }^{22}$ zoals dat de procespartij die daartoe het gemakkelijkst in staat is, gehouden is om dat bewijsmateriaal in het geding te brengen. ${ }^{23}$ Voordeel van de billijkheidsleer is haar souplesse. ${ }^{24}$ Een nadeel is dat het lastig is om van tevoren te bepalen welke partij de bewijslast draagt, hetgeen afbreuk zou kunnen doen aan de rechtszekerheid. ${ }^{25}$ De bewijslast hangt immers af van de concrete omstandigheden van het geval. Dit bezwaar bleek doorslaggevend voor de wetgever, die daarom de voorkeur gaf aan de objectiefrechtelijke theorie.

De keuze van de wetgever was echter niet absoluut: hij koos voor een gematigde objectiefrechtelijke leer. Ingevolge de slotzin van art. $150 \mathrm{Rv}$ kan op grond van de redelijkheid en

18. A. Anema, m.m.v. P.J. Verdam, Mr. C. Asser's Handleiding tot de beoefening van het Nederlands burgerlijk recht. $V$. Van bewijs, Zwolle: W.E.J. Tjeenk Willink 1953, p. 69; zie ook I. Giesen, Bewijs en aansprakelijkheid. Een rechtsvergelijkend onderzoek naar de bewijslast, de bewijsvoeringslast, het bewijsrisico en de bewijsisico-omkering in het aansprakelijkheidsrecht (diss. Tilburg), Den Haag: Boom Juridische uitgevers 2001, p. 88; D.J. Veegens \& K. Wiersma, Het nieuwe bewijsrecht in burgerlijke zaken, Zwolle: Tjeenk Willink 1973, p. 82; Asser Procesrecht/ Asser $32017 / 279$.

19. Giesen 2001, p. 88.

20. Vgl. over het niet-bestaan van volmachtgever HR 22 november 2013, ECLI:NL:HR:2013:1384, NJ 2014/114 (Zandvliet/Vlielander).

21. Asser/Anema $V V$ an bewijs 1953, p. 81-86 ('procesrechtelijke theorie'), Pitlo/Rutgers \& Krans 2014, p. 33-34; H.J.W. Alt, Stelplicht en bewijslast in het nieuwe arbeidsrecht, Deventer: Wolters Kluwer 2017, p. 13-14.

22. Asser/Anema $V$ Van bewijs 1953, p. 82 e.v.

23. Asser/Anema VVan bewijs 1953, p. 85.

24. Giesen 2001, p. 89.

25. Ibidem. 
billijkheid de bewijslast worden omgekeerd, ${ }^{26}$ zodat het bewijsrisico bij verweerder komt te liggen. ${ }^{27}$ De Hoge Raad heeft aangegeven dat omkering op grond van art. $150 \mathrm{Rv}$ terughoudend moet worden toegepast. ${ }^{28}$

\subsection{De verzwaarde motiveringsplicht als uitvloeisel van de billijkheid}

De billijkheidsleer is echter ook op andere wijze doorgesijpeld. Wanneer in bepaalde gevallen eiser in motiveringsnood verkeert, en dientengevolge de gestelde feiten niet kan bewijzen zonder medewerking van verweerder die wel over de gegevens beschikt dan wel behoort ${ }^{29}$ te beschikken, verlangt de verzwaarde motiveringsplicht ${ }^{30}$ van de verweerder dat hij zijn stellingen uitvoerig moet motiveren en de eiser aanknopingspunten voor diens bewijslevering moet verschaffen. ${ }^{31}$ Het zou anders onmogelijk worden voor eiser om te slagen in de bewijslevering. ${ }^{32}$ De verzwaarde motiveringsplicht kan bijvoorbeeld rusten op een aansprakelijk gestelde notaris, ${ }^{33}$ arts, ${ }^{34}$ wegbeheerder (dat er voor de wegbeheerder beperkte financiële middelen beschikbaar waren $)^{35}$ en financiële dienstverlener. ${ }^{36}$ De ratio van de verzwaarde motiveringsplicht is dat in dergelijke gevallen de verweerder de partij is die geacht mag worden te beschikken over relevante gegevens (zoals het dossier in het geval van de arts) ${ }^{37}$ en deze aan de eiser te verschaf-

26. Dit houdt in dat het bewijsrisico bij de verweerder komt te liggen. De wettelijke en jurisprudentiële vermoedens vallen buiten het bereik van de opvatting van de omkering van de bewijslast in enge zin, omdat het bewijsrisico daar niet komt te liggen bij verweerder. Zie Heemskerk 2015, p. 99; Pitlo/Rutgers \& Krans 2014, p. 37 e.v.; Snijders, Klaassen \& Meijer 2017, p. 290; H.W.B. Thoe Schwartzenberg, Civiel bewijsrecht voor de rechtspraktijk, Apeldoorn-Antwerpen: Maklu 2011, p. 77 e.v.; zie anders Asser Procesrecht/Asser 32017/290.

27. Asser Procesrecht/Asser 3 2017/292 (Asser wijkt af van deze terminologie en noemt dit de omkering van het bewijsrisico); vgl. Snijders, Klaassen \& Meijer 2017, p. 287 e.v.; Heemskerk 2015, p. 99.

28. HR 24 juni 2016, ECLI:NL:HR:2016:1272, NJ 2016/401, m.nt. S. Perrick; HR 9 september 2005, ECLI:NL:PHR:2005:AT8238, NJ 2006/99 (Zeeuwse notaris); HR 20 januari 2006, ECLI:NL:PHR: 2006:AU4529, NJ 2006/78 (B./Interpolis).

29. Snijders, Klaassen \& Meijer 2017, p. 294.

30. Zie nader over de verzwaarde motiveringsplicht F.J.P. Lock, 'De verdeling van stelplicht en bewijslast tussen de consument en de tekortschietende kredietverstrekker; een Nederlands en Europees perspectief, NTBR 2016/16, afl. 4, p. 114-122; B.M. Paijmans, 'De verzwaarde stelplicht revisited', NTBR 2016, afl. 2, p. 4-14; Pitlo/Rutgers \& Krans 2014, p. 65-68; Alt 2017, p. 61; A. Hedeman, De verzwaarde stelplicht. De afbakening van een processuele mededelingsplicht, Tilburg: Celsus juridische uitgeverij 2009, p. 7 e.v.; Snijders, Klaassen \& Meijer 2017, p. 294; Thoe Schwartzenberg 2011, p. 91.

31. Asser Procesrecht/Asser 3 2017/307; zie ook Giesen 2001, p. 113; De Bock 2011, p. 229.

32. Concl. A-G Asser, ECLI:NL:HR:1997:ZC2244, bij HR 10 januari 1997, NJ 1999/286, nr. 2.9.

33. HR 19 februari 2016, ECLI:NL:HR:2016:288, NJ 2016/295.

34. Zie bijv. HR 15 juni 2007, ECLI:NL:HR:2007:BA3587, NJ 2007/335, m.nt. K. van der Meer en HR 20 april 2007, ECLI:NL:HR: 2007:BA1093.

35. HR 4 april 2014, ECLI:NL:HR:2014:831, NJ 2014/368, m.nt. T. Hartlief (Reaal/Gemeente Deventer).

36. HR 11 juli 2014, ECLI:NL:HR:2014:1634 (concl. A-G Wissink)

37. Dit vloeit in veel van deze gevallen voort uit art. 7:403 BW, dat impliciet de opdrachtnemer verplicht om informatie te bewaren over de uitvoering van de opdracht. Vgl. ook HR 28 september 2018, ECLI:NL:HR:2018:1776. fen teneinde daarmee (uiteindelijk) te bewerkstelligen dat de rechter de beschikking krijgt over alle relevante feiten en bewijsmateriaal. ${ }^{38}$ Hiermee worden de twee in paragraaf 2.1 genoemde bezwaren ondervangen: de partij die niet over relevant bewijsmateriaal beschikt of dit minder gemakkelijk kan verzamelen, wordt geholpen.

De rechter heeft een zekere vrijheid ten aanzien van de mogelijke sancties:

'[I]ndien het (...) zijn verweer onvoldoende motiveert en de eiser aldus onvoldoende aanknopingspunten biedt voor een meer specifieke onderbouwing van zijn stelling, zal de rechter voors; hands moeten oordelen dat de eiser op dat punt aan zijn stelplicht heeft voldaan en het gestelde, bij gebreke van een voldoende gemotiveerd verweer, voorshands als vaststaand moeten aannemen, of zelfs de bewijslast op dat punt kunnen omkeren. ${ }^{39}$

\subsection{Depubliekrechtelijke theorie}

Vaak wordt vergeten dat er in het verleden ook een derde theorie voor de bewijslastverdeling is voorgesteld: de publiekrechtelijke theorie van Moltzer. ${ }^{40}$ Veegens en Wiersma volstaan in 1973 louter met de opmerking dat de publiekrechtelijke theorie bij niemand instemming heeft gevonden. ${ }^{41}$

In deze theorie draaide het niet om het belang van partijen, maar om het publieke belang dat in acht genomen moest geworden. Daarmee bedoelde Moltzer dat 'de rechter zijn hoge functie als rechtsbedeler alleen kan vervullen als hij de middelen bezit, om zich een voorstelling te vormen omtrent de feiten, die geheel is overeenkomstig de waarheid'. Op partijen rust 'de publiekrechtelijke verplichting om hunnerzijds met alle mogelijke middelen de waarheid tevoorschijn te brengen. De plicht moet worden bekrachtigd door strafbepalingen.' Moltzer omschrijft deze theorie als volgt:

'(...) dat in het civielproces de rechter niet slechts door partijen wordt geroepen om het tusschen haar gerezen geschil tot een welgemotiveerde logische beslissing te brengen, maar tevens van overheidswege de hooge tak zich ziet opgedragen, om met zijne door het oppermachtig gezag van den Staat gesteunde uitspraak voor altijd tusschen partijen een zoodanige feitelijke verhouding te handhaven of te verwezenlijken, als bij zijn gewijsde door hem voor rechtmatig mocht worden erkend.'

Strikt genomen is de publiekrechtelijke theorie eigenlijk geen theorie over bewijslastverdeling. Immers, alle procespartijen hebben de plicht om de aan het geding ten grondslag liggende feitelijke beweringen met de gegevens die daartoe tot haar

38. De Bock 2011, p. 230.

39. HR 4 april 2014, ECLI:NL:HR:2014:831, NJ 2014/368, m.nt. T. Hartlief (Reaal/Gemeente Deventer), r.o. 3.6.3.

40. J.P. Moltzer, Van bewijs in het algemeen en van schriftelijk bewijs, Den Haag: Belinfante 1904, p. 25-39. Zie ook Asser/Anema V Van bewijs 1953, p. $72-73$.

41. Veegens \& Wiersma 1973, deel 1, p. 77. Meer concrete kritiek is te vinden bij Asser/Anema VVan bewijs 1953, p. 80. 
beschikking staan te staven. In essentie gaat het dus om wat we tegenwoordig een waarheidsplicht noemen.

\section{De waarheidsplicht}

\subsection{De waarheidsplicht en haar sancties}

Het doel van de in 2002 ingevoerde waarheidsplicht is dat procespartijen ervoor zorgen dat alle voor de beslissing van belang zijnde feiten (en bewijsmateriaal) boven tafel komen, opdat de rechter een beslissing kan nemen op basis van de werkelijke gang van zaken. ${ }^{42}$ De verplichting van partijen om te voldoen aan de waarheidsplicht geldt in elk stadium van de procedure. ${ }^{43}$ Wanneer een procespartij niet voldoet aan de waarheidsplicht, kan de rechter daaruit 'de gevolgtrekking maken die hij geraden acht'. ${ }^{44}$ De waarheidsplicht legt op procespartijen ook de verplichting op om belastend bewijsmateriaal over te leggen dat het eigen standpunt ontkracht. ${ }^{45} \mathrm{Er}$ is een gezamenlijke verantwoordelijkheid van procespartijen om alle relevante gegevens aan de rechter beschikbaar te stellen. ${ }^{46}$ De strekking van de gezamenlijke verantwoordelijkheid is dat procespartijen en de rechter zich inspannen teneinde zowel 'procedurele als materiële rechtvaardigheid (qua uitkomsten) te benaderen'. ${ }^{47}$ Ook schrijft Giesen dat 'gegeven het óók aanwezige publieke karakter en belang van de rechtspleging, (...) partijwensen niet (langer) de boventoon [kunnen] voeren en (...) het civiele proces, bezien vanuit dat publieke belang, zo goed mogelijk ingericht moet worden'. ${ }^{48}$

Met betrekking tot de sancties die de rechter kan opleggen bij schending van de waarheidsplicht is de wetgever vaag gebleven. ${ }^{49}$ De rechter heeft een discretionaire bevoegdheid over de aan de schending te verbinden sancties. ${ }^{50}$ Zo heeft de wetgever over de sancties het volgende opgemerkt:

'Wel is het natuurlijk zo dat de nalatige partij ook processueel moet kunnen worden "afgerekend" op zijn gedrag. Artikel [21 Rv] biedt daartoe ook ruimte. Zo zal de rechter de bewijslast van de nalatige partij kunnen verzwaren, of die partij bij de beslissing over de proceskosten de rekening voor zijn gedrag presenteren. Ook kan de rechter, wanneer de onjuistheid of onvolledigheid van de stellingen is gebleken en de nalatige partij zijn stellingen wenst uit te

42. Kamerstukken II 1999/2000, 26855, 3, p. 53; zie ook De Bock 2011, p. 54-55.

43. Van Mierlo, in: T\&C Burgerlijk procesrecht 2002, art. $21 \mathrm{Rv}$, aant. 3 (online, bijgewerkt 1 januari 2018).

44. Art. $21 \mathrm{Rv}$.

45. Asser Procesrecht/Asser 3 2017/40; zie evenzo C.J.M. Klaassen, 'Spreken is zilver, zwijgen is fout', NJB 2002, afl. 30, p. 1450-1458, p. 1452. Vgl. reeds vóór 2002: HR 28 september 2001, ECLI:NL:HR:2001:ZC3656, NJ 2002/104.

46. Asser Procesrecht/Giesen 1 2015/513, evenzo Asser Procesrecht/Asser 3 $2017 / 51$.

47. Asser Procesrecht/Giesen $12015 / 514$

48. Asser Procesrecht/Giesen $12015 / 516$

49. Kamerstukken II 1999/2000, 26855, 3, p. 52; zie ook C.J.A. Seinen, 'De gevolgtrekking die hij geraden acht. Sancties op schending van de waarheidsplicht', TCR 2014, afl. 3, p. 85.

50. Ibidem. breiden met nieuwe feiten, deze buiten beschouwing laten wegens strijd met de goede procesorde. ${ }^{51}$

De Hoge Raad heeft in 2011 twee uitspraken ${ }^{52}$ gewezen met betrekking tot de sancties die opgelegd kunnen worden bij schending van de waarheidsplicht. De daarin gegeven overwegingen gaven echter weinig richting:

'De rechter mag ambtshalve oordelen dat een van partijen of beide partijen in strijd heeft dan wel hebben gehandeld met hun in art. 21 bedoelde verplichting en daaraan, ook zonder dat partijen daarover specifiek hebben gedebatteerd, gevolgen verbinden die in overeenstemming zijn met de aard van en de ernst van deze schending van de desbetreffende verplichting. ${ }^{53}$

Vanwege de discretionaire bevoegdheid van de rechter en het feitelijke karakter van de opgelegde sanctie bestaat er weinig ruimte voor toetsing in cassatie. ${ }^{54}$ De Hoge Raad toetst marginaal en de gekozen sanctie dient in overeenstemming te zijn met de aard en de ernst van de schending in een concreet geval. 55

De sancties als gesuggereerd door de wetgever lijken overeen te komen met de sancties die opgelegd kunnen worden bij een schending van de verzwaarde motiveringsplicht (par. 2.3). In de rechtspraak is geen duidelijke lijn te ontwaren. ${ }^{56}$

\subsection{De waarheidsplicht als versmelting van de billijkheidsleer en publiekrechtelijke theorie}

Ten aanzien van het overleggen van bewijsmateriaal zijn er dus tegenwoordig twee concurrerende leerstukken met eigen sanctiestelsels. Reeds in 2002 heeft Klaassen opgemerkt dat de spanning tussen de waarheidsplicht en de bewijslastverdeling noopt tot een herziening van het burgerlijk procesrecht. ${ }^{57}$

De waarheidsplicht kan naar geldend recht het beste als meer fundamenteel worden beschouwd. $\mathrm{Zij}$ is breder, bestrijkt meer aspecten dan alleen bewijslast en bewijsrisico, en wordt ook in althans een deel van de literatuur als principieel uitgangspunt van het bewijsrecht gezien. ${ }^{58}$ Theoretisch bezien lijkt het, gelet op de uitdrukkelijke doelstellingen van de wetgever en de groeiende consensus in de literatuur, dan ook zuiverder uit te gaan van de waarheidsplicht als algemeen kader, waarbinnen de gedetailleerde regels van de bewijslastverdeling

51. Kamerstukken II $1999 / 2000,26855$, 5, p. 25 . Het 'verzwaren' van de bewijslast is strikt genomen onmogelijk, waarschijnlijk wordt hiermee bedoeld de verzwaarde motiveringsplicht.

52. HR 25 maart 2011, ECLI:NL:HR:2011:BO9675, NJ 2012/627; zie ook HR 18 november 2011, ECLI:NL:HR:2011:BS1706.

53. HR 25 maart 2011, ECLI:NL:HR:2011:BO9675, NJ 2012/627, r.o. 3.3 .

54. Asser Procesrecht/Asser $32017 / 194$.

55. Seinen 2014, p. 85; zie voor een overzicht van de gevolgtrekking die de rechter kan maken Teuben, in: GS Burgerlijke Rechtsvordering, art. 21 Rv, aant. 3.

56. Seinen 2014, p. 84-95.

57. Klaassen 2002, p. 1458.

58. Hammerstein, De Bock \& Asser 2017, p. 11 en 29; ook Asser Procesrecht/Asser $32017 / 75$ en De Bock 2011, p. 72. 
een plaats kunnen krijgen. Dat neemt niet weg dat de waarheidsplicht omgekeerd enige aspecten van vroegere theorieën over de bewijslastverdeling lijkt over te nemen.

De waarheidsplicht neemt van de publiekrechtelijke theorie over de verplichting om bewijsmateriaal aan te dragen. Het verschil tussen de publiekrechtelijke theorie en de waarheidsplicht van art. $21 \mathrm{Rv}$ is echter dat de publiekrechtelijke theorie uitgaat van een strafrechtelijke sanctie. ${ }^{59} \mathrm{Bij}$ de waarheidsplicht is er een processuele sanctie mogelijk.

De waarheidsplicht neemt van de billijkheidsleer over het belang van de mogelijkheid van een partij om bewijsmateriaal aan te dragen. Overigens is het voor een partij ook gemakkelijker om materiaal dat zich bij de andere partij bevindt te verkrijgen door de exhibitieplicht (art. 843a Rv) en het bewijsbeslag. ${ }^{60}$ Er zijn echter wel twee verschillen tussen de waarheidsplicht en de billijkheidsleer. Als eerste heeft de waarheidsplicht een genuanceerd sanctiestelsel, in tegenstelling tot de billijkheidsleer. De billijkheidsleer werkt alleen via de bewijslastverdeling en het daaruit voortvloeiende bewijsrisico, wat een tamelijk grofmazig instrument is. Voordeel van de bewijslastverdeling is weer dat dit instrument een duidelijk en afgebakend gevolg geeft: het gaat alleen om het concrete feit dat bewezen moest worden. Ten tweede is bij de bewijslastverdeling (dus ook bij de billijkheidsleer) altijd sprake van één partij die gegevens over moet leggen, ofwel de eiser, ofwel de verweerder. De waarheidsplicht daarentegen legt tegelijkertijd een plicht op aan eiser en verweerder om gegevens over te leggen. Dat kan betekenen dat voor een bepaald feit beide partijen de relevante materialen over moeten leggen. ${ }^{61}$

De vergelijking met de billijkheidsleer is ook in ander opzicht instructief. Het voornaamste bezwaar dat werd opgeworpen voor het aannemen van de billijkheidsleer als heersende leer, was dat van tevoren niet gegeven is wie de bewijslast draagt, hetgeen afbreuk zou doen aan de rechtszekerheid. ${ }^{62}$ Onder het regime van de waarheidsplicht is er geen onzekerheid over wie materiaal over moet leggen: die plicht geldt immers voor alle partijen. Ten aanzien van het gevolg van een eventuele nalatigheid scoort de waarheidsplicht echter slechter. Het is onduidelijk welke sanctie wordt opgelegd en van welke omstandigheden dit afhankelijk is. Deze wending in de theorie is opmerkelijk en heeft verrassend weinig kritiek ondervonden.

In het verleden heeft de rechtszekerheid gewonnen van de billijkheid. Nu zijn de posities omgedraaid. Daar is iets voor te zeggen: de veelgeroemde rechtszekerheid en eenvoud van de objectieve bewijslastverdeling bleken in de praktijk betrekkelijk: een uitgave als Stelplicht \& Bewijslast geeft aan dat juristen in de praktijk grote moeite hebben om de bewijslastverdeling te bepalen. Daarnaast bleek ook uit de in paragraaf 2 genoemde aanvullingen op de bewijslast dat de objectieve leer in de praktijk voor een deel overtroefd wordt door bijzondere regels,

59. Asser/Anema $V$ Van bewijs 1953, p. 72; zie voorts par. 3.3.

60. HR 13 september 2013, ECLI:NL:HR:2013:BZ9958, NJ 2014/455 (Molenbeek/Begeer).

61. Zoals gezegd nuanceert de verzwaarde motiveringsplicht dit weer.

62. Giesen 2001, p. 89; Asser Procesrecht/Asser 3 2017/285. in het bijzonder de verzwaarde motiveringsplicht, die meer recht doen aan de processuele rechtvaardigheid in het concrete geval.

Toch blijkt uit de onzekerheid over de toepassing van het sanctiestelsel van art. 21 en $22 \mathrm{Rv}$ dat inderdaad de rechtszekerheid te lijden heeft onder het regime van de waarheidsplicht.

\subsection{De bewijslastverdeling ingepast in de waarheidsplicht}

Zoals hierboven betoogd is in het huidige recht de bewijslastverdeling een onderdeel van het algemene rechterlijke streven naar de materiële waarheid, dat mede tot uitdrukking komt in de waarheidsplicht. ${ }^{63}$ Dit sluit ook aan bij het gegeven dat art. $21 \mathrm{Rv}$ onderdeel is van de algemene bepalingen van het Wetboek van Burgerlijke Rechtsvordering. De waarheidsplicht is breder en zorgt ervoor dat de rechter over meer informatie beschikt dan enkel op grond van de bewijslastverdeling. ${ }^{64}$ Dit wijkt af van de handboeken ${ }^{65}$ over het bewijsrecht, die nog steeds vertrekken vanuit het oude systeem waar de bewijslastverdeling het uitgangspunt is.

In het nieuwe systeem rust, anders dan in het oude systeem, op beide partijen de plicht om (belastend) bewijsmateriaal in te brengen. De waarheidsplicht zorgt - mits partijen deze plicht naleven - ervoor dat de rechter over meer bewijsmateriaal beschikt dan vroeger. Toch blijft de bewijslastverdeling in zoverre van belang dat als alle bewijsmateriaal is overgelegd er zich nog steeds een non liquet kan voordoen. De onbewezen feiten komen in zulke gevallen nog steeds voor rekening van degene die conform de bewijslastverdeling de bewijslast en dus ook het bewijsrisico draagt. ${ }^{66}$ Mogelijkerwijs is er wel minder vaak een non liquet aan de orde dan vroeger omdat de rechter over meer bewijsmateriaal beschikt. De verzwaarde motiveringsplicht heeft in dit stelsel geen functie meer, want volgt al uit de waarheidsplicht. ${ }^{67}$

Het oorspronkelijke stelsel van bewijslastverdeling had dus geen plicht om materiaal over te leggen, alleen een 'sanctie' in de vorm van het bewijsrisico. Dit werd aangevuld met een verzwaarde motiveringsplicht die met sancties werd afgedwongen. Onder het regime van de waarheidsplicht bestaat het voornaamste handhavingsinstrument uit de sancties voor het niet voldoen aan de waarheidsplicht, maar zal er ook een regeling moeten zijn voor het bewijsrisico indien partijen voldoen aan hun waarheidsplicht. Hierdoor kan er spanning ontstaan tussen deze sancties en de bewijslastverdeling. Hoe gaat de praktijk hiermee om?

63. Het bewijsrecht kan thans niet meer los worden gezien van de waarheidsplicht: Hammerstein, De Bock \& Asser 2017, p. 11.

64. Ook Asser schrijft dat het bewijsrecht een beperkte reikwijdte heeft; zie daarvoor Asser Procesrecht/Asser $32017 / 51$.

65. Asser Procesrecht/Asser 3 2017/270; Snijders, Klaassen \& Meijer 2017, p. 267; Pitlo/Rutgers \& Krans 2014, p. 36 e.v.; Alt 2017, p. 15 e.v.; Heemskerk 2015, p. 98 e.v.

66. Zie reeds Asser/Anema $V$ Van bewijs 1953, p. 73 ten aanzien van de publiekrechtelijke theorie; vgl. Giesen 2002, p. 92.

67. Klaassen 2002, p. 1452. 


\section{De praktijk van waarheidsplicht en bewijslastverdeling}

\subsection{Inleiding}

De sancties bij schending van de waarheidsplicht vormen geen helder stelsel. ${ }^{68}$ Een deel van de sancties verwijst naar de bewijslastverdeling: dit onderstreept dat de waarheidsplicht theoretisch bezien boven de bewijslast staat. Deze sancties laten echter ook zien dat de waarheidsplicht lastig te sanctioneren is en vooral handen en voeten krijgt doordat zij gevolgen heeft voor de bewijslastverdeling en toewijzing van de vordering.

Duidelijk toegevoegde waarde hebben de nevensancties als proceskostenveroordeling: deze hebben als voordeel dat zij ook gebruikt kunnen worden waar het niet wenselijk of passend is om aan de bewijslast te morrelen. Gedacht kan worden aan gevallen waarbij bewijsmateriaal uit strategische overwegingen laat in de procedure wordt ingebracht, maar niet zodanig dat gezien de aard en omvang van het bewijsmateriaal de wederpartij daarop niet adequaat kan reageren. ${ }^{69}$ Een proceskostenveroordeling lijkt, gezien de aard van de schending, in een dergelijk geval passend. ${ }^{70}$

De vraag is nu hoe deze sancties worden toegepast, terwijl ook de regels van bewijslastverdeling van toepassing zijn.

\subsection{Zes categorieën}

Als we de theoretische mogelijkheden bezien, zijn dit de mogelijke gevallen (ervan uitgaande dat op eiser de bewijslast rust voor het aan de orde zijnde feit):

1. Partijen voldoen aan hun waarheidsplicht: in dat geval worden de gewone regels van bewijslastverdeling toegepast, inclusief het bewijsrisico in geval van een non liquet. Dit is het normale geval, wat niet tot opvallende rechtspraak leidt.

2. Eiser voldoet niet aan zijn waarheidsplicht en levert onvoldoende bewijs aan. In zo'n geval kan eveneens worden volstaan met het toepassen van het bewijsrisico en komt men niet toe aan sancties voor schending van de waarheidsplicht. Het zou immers betrekkelijk zinloos zijn dan aan de schending de sanctie te verbinden dat de bewijslast op eiser wordt gelegd (waar die al op rust) of de vordering af te wijzen (wat in casu al het gevolg is van het non liquet). Dit zou anders kunnen zijn als de schending ziet op een ander feit dan het tekortschieten in de bewijslevering. Een voorbeeld is categorie 3 hierna.

3. Eiser voldoet niet aan zijn waarheidsplicht, maar levert wel genoeg bewijs aan. Dit is het geval waarin eiser wel over genoeg gegevens beschikt, maar alleen gunstige gegevens in

68. Zie L. Wijnbergen, 'Informatieplichten in het burgerlijk procesrecht en de geraden geachte gevolgtrekkingen', WPNR 2011/6908, p. 975 e.v.; haars inziens kunnen drie categorieën worden onderscheiden van mogelijke gevolgtrekkingen die de rechter kan maken bij schending van (onder andere) de waarheidsplicht.

69. HR 29 november 2002, ECLI:NL:HR:2002:AF1210, NJ 2004/172, m.nt. H.J. Snijders (Dipasa/Huyton).

70. Zie voor een voorbeeld Rb. Noord-Nederland 4 maart 2015, ECLI:NL:RBNNE:2015:1112, r.o. 4.2. het geding brengt, en ongunstige gegevens achterhoudt. Eiser schendt de waarheidsplicht door geen belastend bewijsmateriaal over te leggen dat in de weg staat aan de toewijzing van (een deel van) de vordering. Het kan dan ook gaan om een verweer waarvoor verweerder de bewijslast draagt; het betreft dan de hierna te noemen categorie 5.

In dergelijke gevallen kan de rechter, ofschoon de eiser wel slaagt in het leveren van bewijs, niettemin de vordering (deels) afwijzen op grond van schending van de waarheidsplicht. De rechtspraak laat hiervan diverse voorbeelden zien. ${ }^{71}$ Een voorbeeld betreft een door de man gedaan verzoek tot nihilstelling van de te betalen alimentatie. ${ }^{72}$ Rechtbank en hof hebben echter de te betalen alimentatie gewijzigd en voor een lager bedrag toegewezen. De man heeft, aldus het hof, onvoldoende inzicht gegeven in zijn draagkracht. Het verzoek is afgewezen op grond van schending van de waarheidsplicht. Deze beslissing werd niet afgedaan op grond van de gewone regels van het bewijsrecht, terwijl het hof dat wel had kunnen doen. Het hof had bijvoorbeeld de zaak kunnen afdoen op grond van het niet komen vaststaan van de onvoldoende draagkracht van de man.

Een ander voorbeeld ${ }^{73}$ is een zaak waarin door FBTO, in de hoedanigheid van eiser, voldoende bewijsmateriaal werd overgelegd waaruit blijkt dat verweerder een betalingsachterstand heeft en daardoor de vordering moest worden toegewezen. Echter, FBTO heeft verzuimd gegevens in te brengen waaruit blijkt dat tussen haar en verweerder een betalingsregeling is overeengekomen. Pas na het verweer van verweerder heeft FBTO de betalingsregeling erkend. FBTO heeft daardoor art. $21 \mathrm{Rv}$ geschonden. De rechtbank neemt het FBTO kwalijk dat zij dit aanvankelijk heeft proberen te verzwijgen, want deze betalingsregeling als zodanig staat aan de toewijzing van de vordering in rechte in de weg. De vordering is op grond van schending van de waarheidsplicht afgewezen.

4. Verweerder voldoet niet aan zijn waarheidsplicht, maar eiser levert genoeg bewijs aan. In zo'n geval volgt opnieuw uit de gewone regels van bewijslast dat eiser gelijk krijgt en dat verweerder hooguit nog zou kunnen worden toegela-

71. Bijv. Rb. Limburg 21 februari 2018, ECLI:NL:RBLIM:2018:1686; Rb. Amsterdam 3 november 2017, ECLI:NL:RBAMS:2017:8152; Rb. Zeeland-West-Brabant 18 januari 2017, ECLI:NL:RBZWB: 2017:610; Rb. Limburg 15 februari 2018, ECLI:NL:RBLIM: 2018:1556; Rb. Rotterdam 6 juli 2017, ECLI:NL:RBROT:2017:5248; Rb. Den Haag 6 september 2017, ECLI:NL:RBDHA:2017:10121; Rb. Noord-Nederland 23 maart 2016, ECLI:NL:RBNNE:2016:1274; Rb. Zeeland-West-Brabant 7 oktober 2015, ECLI:NL:RBZWB: 2015:6488; Rb. Overijssel 14 oktober 2015, ECLI:NL:RBOVE: 2015:5220; Rb. Midden-Nederland 2 augustus 2017, ECLI:NL:RBMNE:2017:3941; Rb. Limburg 18 november 2015, ECLI:NL:RBLIM:2015:9663; Rb. Gelderland 28 oktober 2015, ECLI:NL:RBGEL:2015:6599; Hof 's- Hertogenbosch 2 maart 2015, ECLI:NL:GHSHE:2015:1084; Hof 's-Hertogenbosch 9 januari 2018, ECLI:NL:GHSHE:2018:61. In de hiervoor genoemde uitspraken heeft eiser steeds verzuimd (belastende) gegevens in te brengen.

72. HR 29 januari 2016, ECLI:NL:HR:2016:154.

73. Rb. Limburg 22 november 2017, ECLI:NL:RBLIM:2017:11448. 
ten tot leveren van tegenbewijs. Een afzonderlijke sanctie lijkt niet nodig, tenzij men zou willen dat verweerder de gelegenheid voor leveren van tegenbewijs wordt ontnomen: dan zou de rechter direct de vordering kunnen toewijzen zonder gelegenheid te bieden tot het leveren van tegenbewijs.

5. Verweerder voldoet niet aan zijn waarheidsplicht, maar eiser levert niet genoeg bewijsmateriaal aan. In zo'n geval wijst de waarheidsplicht een andere kant op dan de bewijslastverdeling. In de jurisprudentie zijn enkele voorbeelden waar in zo'n geval daadwerkelijk eiser dan in het gelijk wordt gesteld. Dit is toegestaan volgens de sancties op de waarheidsplicht; het laat zien dat in zo'n geval inderdaad de waarheidsplicht prevaleert boven de bewijslastverdeling, zoals ook wel is betoogd in de literatuur. ${ }^{74}$

Een voorbeeld is een zaak omtrent de doorbraak van aansprakelijkheid van de moedermaatschappij (verweerder), waarbij de moedermaatschappij dochtervennootschappen heeft leeggehaald zonder een voorziening achter te laten voor een bestaande crediteur (eiser). ${ }^{75}$ De rechtbank overweegt dat eiser niet meer kan stellen dan hij weet en redelijkerwijs kan weten. Vervolgens is het aan de verweerder op grond van art. $21 \mathrm{Rv}$ om aan te geven hoe de vork in de steel steekt, gelet op de ook op hem rustende plicht feiten aan te voeren. Ten overvloede merkt de rechtbank op dat er geen bewijslast op verweerder rust (r.o. 2.2). De rechtbank oordeelt echter wel dat het verweer van verweerder als onvoldoende onderbouwd moet worden gepasseerd, en dat verweerder heeft nagelaten de rechtbank volledig in te lichten, en wijst om die reden de vordering toe. Het niet inbrengen van bewijsmateriaal op grond van de waarheidsplicht weegt zwaarder dan het niet slagen in het leveren van bewijs door eiser.

Een tweede voorbeeld is een uitspraak ${ }^{76}$ van het Gerechtshof Arnhem-Leeuwarden waarbij eiseres (geïntimeerde in hoger beroep) de rechtbank heeft verzocht tot vaststelling van kinderalimentatie op $€ 600$. Verweerder (appellant in hoger beroep) heeft zowel bij de rechtbank, alsook bij het hof onvoldoende gegevens overgelegd waaruit blijkt dat zijn financiële situatie is verslechterd, opdat de kinderalimentatie op nihil kan worden gesteld. Het hof, net als de rechtbank, constateert dat verweerder de waarheidsplicht heeft geschonden en wijst het verzoek van eiseres in eerste aanleg toe. In deze zaak ziet men dat verweerder over gegevens beschikt die van belang zijn voor de beslissing. Door deze gegevens niet in te brengen heeft verweerder de waar-

74. Hammerstein, De Bock \& Asser 2017, p. 11.

75. Rb. Gelderland 13 juli 2016, ECLI:NL:RBGEL:2016:4686. Zie voor vergelijkbare gevallen Hof Arnhem-Leeuwarden 9 mei 2017, ECLI:NL:GHARL:2017:4003; Hof Amsterdam 15 augustus 2017, ECLI:NL:GHAMS:2017:3300; Hof Arnhem-Leeuwarden 7 juni 2016, ECLI:NL:GHARL:2016:4508; Rb. Noord-Holland 23 maart 2016, ECLI:NL:RBNHO:2016:2240. In deze zaken heeft de man niet genoeg gegevens overgelegd waaruit blijkt dat zijn financiële situatie is verslechterd.

76. Hof Arnhem-Leeuwarden 16 juli 2015, ECLI:NL:GHARL:2015:5374. heidsplicht geschonden, en als sanctie is de vordering toegewezen.

Een andere mogelijkheid is dat de vordering niet rechtstreeks wordt toegewezen, maar dat de door eiser aangevoerde feiten komen vast te staan. ${ }^{77}$

Een alternatieve sanctie in dergelijke gevallen is bewijslastomkering. Een voorbeeld is een uitspraak over de beëindiging van een samenwerkingsovereenkomst tussen een bedrijf in bouwmanagement en advisering in de gezondheidszorg (eiser) ${ }^{78}$ en Erasmus MC. ${ }^{79}$ Erasmus MC had een voorschot betaald: de vraag was of en in hoeverre zij dit terug kon vorderen. Eiser stelde dat het grootste deel van het voorschot is betaald aan een derde (hierna: Uni$\log$ ), die met toestemming van Erasmus MC werkzaamheden zou uitvoeren (r.o. 4.3). Ter onderbouwing beriep eiser zich op een factuur van Unilog. ${ }^{80}$ Dit bedrag stond echter niet op een door Unilog aangeleverde lijst van openstaande facturen. Eiser verklaarde daarop dat dit bedrag reeds was voldaan. Ter zitting heeft eiser echter erkend dat de factuur nimmer is voldaan. De rechtbank verbindt aan het bewust onjuist informeren de gevolgtrekking dat de bewijslast en het bewijsrisico met betrekking tot de stellingen van eiser over de gestelde overeenkomst met Unilog en de gestelde toestemming van Erasmus MC volledig op eiser komen te rusten (r.o. 4.7). Blijkens deze uitspraak is als gevolg van de schending van de waarheidsplicht de bewijslast omgekeerd. Dit bevestigt dat de waarheidsplicht voorgaat. Eerst dient men te kijken naar de aard van de schending van de waarheidsplicht. Indien de schending zwaar genoeg is, kan de bewijslast worden omgekeerd. Wanneer dat niet het geval is, dan kunnen lichtere sancties worden opgelegd.

6. Beide partijen voldoen niet aan hun waarheidsplicht. In zo'n geval is er geen evidente processuele sanctie met goed resultaat. Een voorbeeld van een dergelijk geval is een zaak waar onvoldoende feiten waren gesteld voor een adequate schadebegroting. ${ }^{81}$ De neiging lijkt dan te zijn om eiser in zo'n geval in het ongelijk te stellen, wat reeds het gevolg zou zijn van de gewone bewijslastverdeling. Ook dan prevaleert dus het traditionele stelsel van bewijslastverdeling en heeft de schending van de waarheidsplicht geen passend gevolg. ${ }^{82}$

77. Bijv. Hof Arnhem-Leeuwarden 20 december 2013, ECLI:NL:GHARL: 2013:10095: bij alimentatievaststelling had de man een bedrijf van hem verzwegen, zodat werd uitgegaan van de stellingen van de vrouw over zijn inkomen. Daarnaast werd de man in de proceskosten veroordeeld.

78. Kortheidshalve zal ik in deze zaak spreken van eiser.

79. Rb. Rotterdam 25 november 2015, ECLI:NL:RBROT:2015:9455. Vgl. Rb. Alkmaar 24 maart 2010, ECLI:NL:RBALK:2010:BM3530.

80. Erasmus MC betwistte dat dit werkzaamheden betrof ten behoeve van Erasmus MC.

81. HR 9 december 2011, ECLI:NL:HR:2011:BR5211, NJ 2011/601. Voor schadebegroting geldt overigens dat de rechter bij ontbreken van voldoende feiten toch zal moeten schatten.

82. Men zou overigens kunnen verdedigen dat er nuances moeten worden aangebracht, bijv. naargelang de ernst van de schending of de mate van verwijtbaarheid. In dergelijke gevallen kan de rechter taxeren: zie nader hierover concl. A-G Huydecoper, ECLI:NL:HR:2011:BO9675, bij HR 25 maart 2011, NJ 2012/627, nr. 18. 
Tot slot moet erop worden gewezen dat schending van de waarheidsplicht niet altijd met een sanctie wordt bestraft. In een onderzoek naar jurisprudentie van feitenrechters ${ }^{83}$ zijn dertien uitspraken ${ }^{84}$ gevonden waarin een schending van de waarheidsplicht is geconstateerd die onvoldoende zwaarwegend was om daaraan een sanctie te verbinden. Een voorbeeld is een uitspraak van de Rechtbank Noord-Nederland waar eiseres bij dagvaarding de door haar gevorderde facturen heeft overgelegd. Echter, zij heeft pas een paar dagen voor de comparitie de specificaties daarvan overgelegd. ${ }^{85}$ De rechtbank vond het te ver gaan om daaraan een sanctie te verbinden op grond van schending van de waarheidsplicht.

Een tweede voorbeeld is een uitspraak ${ }^{86}$ van de Rechtbank Midden-Nederland waarin twee hypotheekgevers de hypotheeknemer (Regiobank) aansprakelijk hebben gesteld voor de restschuld na de verkoop van het onderpand en afwikkeling van de hypotheek. Regiobank stelt dat de hypotheekgevers art. $21 \mathrm{Rv}$ hebben geschonden, omdat zij hun kennis en ervaring, hun inkomens- en vermogensposities niet aan de rechtbank kenbaar hebben gemaakt. De rechtbank ziet geen aanleiding om daaraan een sanctie te verbinden, omdat de vordering op een andere grond (niet aantonen van schending van de zorgplicht) kan worden afgewezen.

Uit deze gevalsanalyse en rechtspraakonderzoek blijkt dat de waarheidsplicht in veel gevallen slechts op de achtergrond hoeft te functioneren omdat de zaak al eenvoudig op het bewijsrisico kan worden afgedaan. Daarnaast blijkt in enkele gevallen (zoals bij categorie 3 besproken) dat de rechter regelmatig een zaak afdoet op grond van schending van de waarheidsplicht, terwijl ook regels van bewijslastverdeling tot eenzelfde resultaat hadden kunnen leiden. In gevallen waar bewijslast en waarheidsplicht op elkaar botsen, prevaleert de waarheidsplicht (categorie 5). Daarnaast blijkt dat schending van de waarheidsplicht niet in alle gevallen tot een sanctie leidt, en in zoverre de waarheidsplicht onvoldoende kracht heeft. Naar het lijkt speelt de aard van de schending van de waarheidsplicht een rol bij de zwaarte van de opgelegde sanctie(s).

83. Dit onderzoek was onderdeel van de scriptie van de eerste auteur. Rechtspraak van 1 januari 2015 tot en met februari 2018 is geanalyseerd.

84. Zie Hof Den Haag 6 december 2016, ECLI:NL:GHDHA:2016:3530; Hof Arnhem-Leeuwarden 12 januari 2016, ECLI:NL:GHARL: 2016:117; Hof Den Haag 13 oktober 2015, ECLI:NL:GHDHA: 2015:2748; Hof Amsterdam 31 maart 2015, ECLI:NL:GHAMS: 2015:1197; Rb. Gelderland 26 januari 2018, ECLI:NL:RBGEL: 2018:481; Rb. Rotterdam 11 april 2017, ECLI:NL:RBROT: 2017:2750; Rb. Limburg 8 maart 2017, ECLI:NL:RBLIM:2017:2082; Rb. Den Haag 25 januari 2017, ECLI:NL:RBDHA:2017:785; Rb. Midden-Nederland 25 november 2016, ECLI:NL:RBMNE:2016:6290; Rb. Gelderland 2 november 2016, ECLI:NL:RBGEL:2016:5872; Rb. Midden-Nederland 24 augustus 2016, ECLI:NL:RBMNE: 2016:4508; Rb. Limburg 30 september 2015, ECLI:NL:RBLIM: 2015:8177; Rb. Noord-Nederland 4 maart 2015, ECLI:NL:RBNNE: 2015:1112.

85. Rb. Noord-Nederland 4 maart 2015, ECLI:NL:RBNNE:2015:1112, r.o. 4.2.

86. Rb. Midden-Nederland 24 augustus 2016, ECLI:NL:RBMNE: 2016:4508.

\subsection{Verdere kanttekeningen bij de waarheidsplicht}

De bovenstaande analyse geeft aanleiding tot enige nadere opmerkingen. Hoewel men theoretisch zou denken dat de rechtspraak vooral draait om de sancties op het niet voldoen aan de waarheidsplicht, blijkt meestal de zaak gewoon op de regels inzake bewijslastverdeling en bewijsrisico te worden afgedaan. Dat kan betekenen dat de waarheidsplicht meestal goed wordt nageleefd en partijen en advocaten dus netjes de rechter helpen. ${ }^{87}$ Het zou echter mede erop kunnen wijzen dat de waarheidsplicht een minder effectief instrument voor bewijslevering is dan wel wordt verondersteld, omdat de handhaving lastiger is dan het lijkt. Dit is om drie redenen het geval:

1. De waarheidsplicht heeft als zwakte dat zij een toerekenbare tekortkoming vereist. Men moet immers vaststellen dat een partij verwijtbaar heeft gehandeld door na te laten bewijsmateriaal over te leggen. Dat is voor de rechter niet altijd eenvoudig vast te stellen. Weliswaar blijkt uit de geanalyseerde jurisprudentie dat in diverse gevallen de rechter wel degelijk op goede grond kan vaststellen dat de waarheidsplicht is geschonden, maar dat laat onverlet dat het zeer wel mogelijk is dat veel andere verzuimen niet voldoende duidelijk zijn voor de rechter en daarom niet tot sancties leiden. In zoverre is van belang dat de bewijslastverdeling op de achtergrond functioneert als een duidelijke basisregel: het bewijsrisico geldt immers ongeacht of een partij daadwerkelijk nalatig is geweest. De subjectivering die inherent is aan de waarheidsplicht maakt het procesrecht onzekerder.

2. Die onzekerheid wordt versterkt doordat er geen eenduidige sanctie is op schending van de waarheidsplicht: de rechter heeft keuzevrijheid. Het belangrijkste argument tegen de billijkheidsleer was destijds de rechtsonzekerheid waar deze toe leidde. In zekere zin is dat nu nog steeds aan de orde, zoals blijkt uit de onduidelijkheid over de toepassing van de sancties bij schending van de waarheidsplicht. ${ }^{88}$ De effectiviteit van de waarheidsplicht wordt verder ondermijnd door de vaststelling dat in diverse gevallen de schending niet als zo ernstig werd beschouwd dat daar een sanctie op werd gesteld.

3. Een verdere zwakte is dat de waarheidsplicht (evenmin als de bewijsaandraagplicht) strikt genomen geen bewaarplicht inhoudt. Soms worden er wel gevolgen verbonden aan het vernietigen van bewijsmateriaal. ${ }^{89}$ Maar als een partij vóór aanvang van de procedure (of zelfs voordat er sprake is van een geschil) bewijsmateriaal heeft vernietigd, staat daar in beginsel geen bewijsrechtelijke sanctie op: een partij is

87. In de literatuur wordt regelmatig iets anders gesuggereerd, maar daar is weinig concreet empirisch bewijs voor, vgl. hierover B. van Zelst, 'Over de noodzaak van een beter geïnformeerde en bredere discussie over geschiloplossing', NJB 2018/1999.

88. Wel is het zo dat die onzekerheid bij de waarheidsplicht pas rijst aan het eind, bij de bepaling van de sancties. Dit lijkt minder problematisch.

89. Hof 's-Hertogenbosch 10 januari 2017, ECLI:NL:GHSHE:2017:31 (Ladder); Rb. Amsterdam 13 oktober 2010, ECLI:NL:RBAMS: 2010:BP7834, r.o. 2.19-2.21 (Documenten); HR 14 november 2014, NJ 2015/193 (Sjoppingspel). 
daarom niet geprikkeld om materiaal te behouden dat in de toekomst nadelig zou kunnen zijn. ${ }^{90}$ Art. $21 \mathrm{Rv}$ verplicht hier niet toe: dat betreft alleen bestaand materiaal. Het bewijsrisico daarentegen hield tenminste nog een prikkel in om zelf materiaal te behouden (voor de zekerheid bij eventuele toekomstige procedures). Dit is een blinde vlek in de discussie over de waarheidsplicht. ${ }^{91}$ De discussie hierover is vooral gevoerd rond de leer van de verzwaarde motiveringsplicht. Een bredere discussie over de billijkheidstheorie van bewijslastverdeling zou hier nuttig zijn, evenals een nader uitgewerkte regeling voor bewaarplichten.

\section{Biedt het wetsvoorstel herziening bewijsrecht verbetering?}

Hierboven zijn enkele zwakten van het huidige stelsel van waarheidsplicht en bewijslastverdeling aangegeven. De vraag is of het wetsvoorstel herziening bewijsrecht tot verbetering leidt, met name omdat dit voorstel de balans verder verschuift naar de waarheidsplicht ten koste van het traditionele bewijsrecht.

Het wetsvoorstel herziening bewijsrecht ${ }^{92}$ heeft als doel het bewijsrecht in civiele procedures te vereenvoudigen en te moderniseren. ${ }^{93}$ De nadruk wordt daarbij gelegd op informatievergaring en bewijsverzameling voorafgaand aan de procedure. Partijen kunnen hun rechtspositie beter inschatten ingeval zij voorafgaand aan een civiele procedure reeds de beschikking hebben over alle relevante informatie. Ingeval een justitiabele niettemin een procedure entameert, dient die procedure - gelet op de preprocessuele informatieverzameling sneller en efficiënter te verlopen.

Hiertoe krijgt de verplichting tot het preprocessueel verzamelen van bewijsmateriaal (en het delen daarvan met de wederpartij) een wettelijke basis (art. 149a Voorstel-Rv). Ingeval een partij gegronde vrees heeft dat bepaalde gegevens die zich niet binnen haar domein bevinden, worden vernietigd of anderszins, kan hierop bewijsbeslag worden gelegd (art. 206 en 207 Voorstel-Rv). De jurisprudentie van de Hoge Raad ten aanzien van het bewijsbeslag wordt daarmee gecodificeerd. ${ }^{94}$

90. Uiteraard afgezien van wettelijke bewaarplichten als art. 2:10 en 3:15i BW.

91. Het conceptwetsvoorstel gaat ook alleen uit van mogelijkheden om materiaal te behouden als er al een geschil is (bijv. door bewijsbeslag).

92. Zie www.internetconsultatie.nl/bewijsrecht.

93. Zie nader over het wetsvoorstel herziening bewijsrecht: NVvP 2018; Alt 2018; De Boer \& De Monchy 2018; Lock 2018, p. 91-92; Verkerk 2018, p. 71-78; S.L. Boersen \& T.R.B. De Greve, 'Information overload en de meeprocederende rechter. Kanttekeningen bij het Conceptwetsvoorstel vereenvoudiging en modernisering bewijsrecht', BER 2018, afl. 8, p. 20-25; A. Hammerstein, 'Modernisering van het bewijsrecht', BER 2018, afl. 8, p. 13-14; H. van Dam-Lely, 'De eigen(aardig)heid van de kantonrechter', TCR 2018, afl. 4, p. 130-131; P.M.P. Frenken, 'Modernisering van het bewijsrecht. Meer mogelijkheden, maar ook meer verplichtingen voorafgaand aan de procedure', BER 2018/174; Y.A. Wehrmeijer \& E.M. Hoogervorst, 'Naar een moderner burgerlijk bewijsrecht?', TCR 2018, afl. 1, p. 1-9; R. Ubels \& T. van Amsterdam, 'Een kritische beschouwing over het Wetsvoorstel ter vereenvoudiging en modernisering van het bewijsrecht', TCR 2019, afl. 1, p. 22-32.

94. HR 13 september 2013, ECLI:NL:HR:2013:BZ9958, NJ 2014/455 (Molenbeek/Begeer)
De preprocessuele informatievergaring brengt daarnaast mee dat een voorlopig getuigenverhoor bijvoorbeeld tijdens een procedure niet meer mogelijk is. ${ }^{95}$ Voorlopige bewijsverrichtingen plegen zo veel als mogelijk voorafgaand aan een procedure te worden gedaan. In het verlengde hiervan kunnen partijen in een procedure geen aanspraak meer maken op het leveren van getuigenbewijs indien daartoe een toereikend bewijsaanbod is gedaan. In plaats daarvan krijgt de rechter een discretionaire bevoegdheid om te beoordelen - nadat een partij daartoe een verzoek heeft gedaan - of een getuigenverhoor noodzakelijk is in het belang van de waarheidsvinding (art. 166 lid 1 Voorstel-Rv). De rechter kan ook ambtshalve partijen bevelen getuigen mee te nemen naar de mondelinge behandeling (art. 166 lid 2 Voorstel-Rv).

Op dit voorstel is om verschillende redenen kritiek geleverd. Onder meer is het bezwaar dat partijen dan voorafgaand reeds uitputtende getuigenverhoren zouden moeten houden die achteraf grotendeels nodeloos blijken, wat een grotere belasting van de rechterlijke macht oplevert dan als het huidige systeem van bewijslast en enquête behouden blijven. ${ }^{96}$ Onder het voorgestelde systeem zijn er minder mogelijkheden dan thans om te bepalen of een getuigenverhoor nodeloos is: ${ }^{97}$ er is immers geen processueel debat waaruit kan worden afgeleid welke feiten betwist en volgens de rechter relevant zijn. ${ }^{98}$

Maar scoort het voorstel dan beter wat betreft de hierboven geïdentificeerde zwakten van het huidige stelsel?

Als we kijken naar het ontbreken van een bewaarplicht (reden 3) biedt de voorgestelde regeling van het bewijsbeslag (voorgesteld art. 206) wel enige verbetering, maar zij heeft geen effect voor gevallen waar het bewijsmateriaal al definitief verloren is gegaan vóórdat eiser de kans heeft gehad bewijsbeslag te vragen. Een versterking van het voorstel met een regeling inzake een bewaarplicht bij een voorzienbaar geschil zou een verbetering vormen.

De andere twee zwakten, de eis van toerekenbare tekortkoming en de onduidelijkheid van sancties, worden niet verbeterd. Om dit uit te leggen is een wat uitvoeriger argumentatie nodig.

Zoals hierboven is beschreven gaan de regels inzake bewijslast ervan uit dat een partij die de bewijslast draagt ook de gelegenheid krijgt om materiaal te vergaren en aan te dragen. Bewijslast impliceert ook bewijskans. ${ }^{99}$ Als dat niet zo zou zijn, is het immers zinloos om van bewijslast te spreken en zou

95. Kritisch hierover: C.J.M. Klaassen, 'Voorlopige bewijsverrichtingen: wat kun en moet je er mee, nu en in de (nabije?) toekomst?', $A A$ 2019, afl. 2, p. 97-108.

96. NVvP 2018, p. 17 (Lock) en 51; Ubels \& Van Amsterdam 2019, p. 25-26.

97. Hier geldt dan de beperkte toets voor toelating van een voorlopig getuigenverhoor.

98. Zie voor een opsomming en verdere kritiek ten aanzien van het wetsvoorstel vereenvoudiging en modernisering bewijsrecht Boersen \& De Greve 2018, p. 20-25.

99. In elk geval voor getuigenbewijs (vgl. art. $166 \mathrm{Rv}$ ). Voor schriftelijke stukken e.d. is het uitgangspunt dat deze onmiddellijk in het geding moeten worden gebracht, maar in de praktijk wordt meestal toegestaan om nadere stukken in te brengen bij conclusie na enquête. 
de rechter gewoon de vordering direct moeten afwijzen. In het traditionele stelsel van bewijsrecht komt dit tot uiting doordat na het voorlopig bewijsoordeel van de rechter een partij een bewijsopdracht krijgt (al dan niet voor het leveren van tegenbewijs). Dit is efficiënt doordat alleen voor de relevante en betwiste (art. $149 \mathrm{Rv}$ ) geschilpunten een partij nader materiaal hoeft aan te dragen (en in het bijzonder getuigen te laten horen). ${ }^{100}$

Onder de vigeur van art. $21 \mathrm{Rv}$ is dit verschoven doordat er meer materiaal vooraf in het geding moet worden gebracht, maar tot nog toe is de bewijskans niet substantieel beperkt. Het voorstel herziening bewijsrecht beoogt echter een principiële verschuiving door de latere bewijskans af te kappen, en in het bijzonder art. $166 \mathrm{Rv}$ in te perken. Dit komt erop neer dat de bewijskans is verplaatst naar de aanvang van de procedure: dát is het moment om alles aan te leveren en alle materialen te vergaren, niet het moment van de door de rechter verleende bewijsopdracht.

Wat betekent dit nu als bepaalde gegevens (in het bijzonder getuigenverklaringen) niet direct bij aanvang van de procedure zijn overgelegd? De regeling van het voorgestelde art. 166 (in combinatie met de toelichting) suggereert dat het niet overleggen van zekere gegevens in beginsel als toerekenbaar (verwijtbaar) wordt gezien. ${ }^{101}$ Dit is een radicale omslag ten opzichte van de huidige praktijk, waarin (zoals we hierboven zagen) het betrekkelijk weinig voorkomt dat daadwerkelijk zodanige verwijtbaarheid wordt geconstateerd. Deze keuze van de wetgever verdient uitdrukkelijk aandacht, en gaat verder dan een louter technische aanpassing van het bewijsrecht voor verbetering van de efficiëntie. Een aanname van verwijtbaarheid kan snel onrechtvaardig zijn, met name nu de onvolledigheid ook te goeder trouw kan zijn ontstaan, doordat een feit of stuk niet als relevant werd gezien. ${ }^{102}$

Hiertegen kan worden ingebracht dat de wetgever uitdrukkelijk de mogelijkheid openlaat dat het niet overleggen van materiaal niet verwijtbaar is. Immers, het voorgestelde art. 166 laat de mogelijkheid open om op een later moment toch nog nadere bewijslevering toe te staan, naar het discretionaire oordeel van de rechter. Allereerst verdient opmerking dat hiermee dus geen verbetering optreedt van de onzekerheid of een sanctie wordt toegepast, en welke. Maar bovendien lijkt het voorgestelde stelsel innerlijk tegenstrijdig. Enerzijds eist de waarheidsplicht dat vooraf alle mogelijk te verkrijgen materialen in het geding worden gebracht, maar anderzijds wordt kennelijk toch de mogelijkheid opengelaten van nadere bewijslevering op een later moment. Maar het voorgestelde art. 166, tweede zin, gaat net als het huidige art. $166 \mathrm{Rv}$ uit van een ter zake doend bewijsaanbod, opdat getuigenverhoor kan worden bevolen. Dit brengt een partij in een catch 22. Hoe kan een partij te goeder trouw nader bewijs aanbieden van een feit als het systeem haar verplicht alle bewijs reeds vooraf aan te leve-

100. Verkerk 2018, p. 76 .

101. Nog daargelaten de mogelijkheid dat pas tijdens de procedure naar boven komt dat een partij haar advocaat (onbewust) onvolledig heeft voorgelicht ten aanzien van de door haar niet relevant geachte gegevens. 102. Verkerk 2018, p. 76; ook Lock 2018, p. 92. ren? Ofwel je kon het voorzien, maar dan had je het moeten leveren, ofwel je kon het niet voorzien, maar dan heb je het ook niet aangeboden, en bij gebrek van een bewijsaanbod vervalt ook de mogelijkheid van een bewijsopdracht. Misschien zou de rechter op grond van het voorgestelde art. 166 lid 2 partijen kunnen bevelen getuigen mee te brengen naar de zitting? Dat werkt echter niet als pas tijdens de zitting blijkt dat bepaalde getuigen nodig zouden zijn. Moeten partijen dan voor de vorm een gratuit bewijsaanbod doen voor alle mogelijke feiten, door alle mogelijke betrokkenen als getuigen te horen? Zo'n algemeen aanbod behoort volgens vaste rechtspraak - terecht - als te weinig specifiek te worden afgewezen. ${ }^{103}$ Kortom, de voorgestelde regeling is niet goed doordacht als het aankomt op de vraag hoe de rechter moet vaststellen wanneer het niet overleggen van materiaal verwijtbaar is, in samenhang met het handhaven van de eis van een bewijsaanbod.

Als laatste levert de inperking van de mogelijkheid van nadere bewijslevering een probleem op voor het sanctiemechanisme voor de waarheidsplicht. De sancties van voorshands oordeel en/of verleggen van de bewijslast worden irrelevant. Immers, als daar geen gelegenheid tot nadere bewijslevering op volgt, is het resultaat onmiddellijk dat het desbetreffende feit wel of niet bewezen wordt verklaard. Hierdoor ondergraaft de voorgestelde regeling zichzelf.

Er blijft slechts een beperkt instrumentarium over van sancties, in het bijzonder de vaststelling van het omstreden feit en de proceskostenveroordeling. De eerstgenoemde sanctie komt erop neer dat de rechter bij wege van fictie aanneemt dat een gesteld feit waar is, en weigert om zich te verdiepen in de werkelijke stand van zaken. Dat is nogal ironisch voor een wetsvoorstel dat juist beoogt de materiële waarheid te laten prevaleren.

Deze overwegingen laten zien dat het van belang is de verhouding tussen waarheidsplicht en bewijslastverdeling goed te doordenken. Het bewijsrisico is een onontbeerlijk element in elke bewijsrechtelijke regeling, in zoverre blijft altijd een rest van bewijslastverdeling over. De sanctiemogelijkheden van de waarheidsplicht kunnen echter niet zomaar parasiteren op het instrumentarium van de bewijslastverdeling als tegelijk de mogelijkheden van nadere bewijslevering worden ingeperkt. Doordat het wetsvoorstel zich onvoldoende rekenschap geeft van het diepere mechanisme van het bewijsrecht, lijkt het tot enkele opvallende tegenstrijdigheden te leiden.

\section{Conclusie}

De waarheidsplicht is in zeker opzicht breder dan bewijslastverdeling, maar is in ander opzicht niet los te denken van de vraag wie het bewijsrisico draagt. De verschuiving naar de waarheidsplicht is te verdedigen, maar bij die ontwikkeling is onvoldoende aandacht besteed aan de bezwaren, die destijds al

103. HR 30 maart 2018, ECLI:NL:HR:2018:482, NJ 2018/167 (D./Stichting Maasstad Ziekenhuis); HR 22 december 2017, ECLI:NL:HR: 2017:3250, NJ 2018/45 (Bencis/X); HR 7 september 2018, ECLI:NL:HR:2018:1433, RVDW 2018/996 (Box Consultants c.s./ Staat). 
bij de rivaliserende bewijstheorieën waren angekaart: het gebrek aan rechtszekerheid. Dit blijkt ook daaruit dat de waarheidsplicht een subjectieve tekortkoming vereist, wat lastiger is aan te tonen dan de objectieve benadering van de bewijslastverdeling. Verder schiet de waarheidsplicht tekort doordat deze zich alleen richt op het produceren van nog bestaand bewijsmateriaal, en geen gevolgen verbindt aan het doelbewust of verwijtbaar vernietigen van bewijsmateriaal vóór de aanvang van de procedure.

Een verbeterd sanctiestelsel zou de waarheidsplicht beter doen aansluiten bij de praktijk van het civiele proces. De voorgestelde aanpassing van het bewijsrecht gaat aan deze problemen voorbij, en dreigt deze zelfs te verergeren. Het is onjuist om het procesrecht als een louter technische kwestie te zien met regels die eenvoudig kunnen worden veranderd: het recht heeft een diepere samenhang, waardoor lukraak aangebrachte wijzigingen snel tot praktische problemen en ongewenste neveneffecten kunnen leiden. Een wetenschappelijke bestudering van het procesrecht is en blijft van groot belang. 